\title{
Evaluation on Training Program Candidates for Head of School Library to Teachers in Bengkulu Province
}

\author{
Adisel $^{1}$, Suryadi $^{2}$, Suparno Eko Widodo ${ }^{3}$ \\ ${ }^{1}$ Doctoral Program, Education Management, Universitas Negeri Jakarta \\ Lecturer of Faculty of Education, IAIN Bengkulu, Indonesia \\ ${ }^{2,3}$ Lecturer, Universitas Negeri Jakarta, Indonesia
}

\begin{abstract}
This study is aimed to evaluate the legal basis and goal of the training program, the training program resources, the implementation process of training program, and the result of the training program for candidate of school library head to the teachers in elementary school, junior high school, senior high school and vocational high school in Bengkulu Province. The quantitative method using Context, Input, Process, and Product (CIPP) is as the evaluation model. The method is performing by using several approaches including the observations, interviews, and documentations. The results show that the training program is consistent with the standard and criteria of the training program. The resultsreveal that the program has a clear basis and purpose. The training program resources also have also qualified with the standard and criteria. In addition the implementation of education and training program has been run in accordance with the objectives of training program. The result of the training program in improving the competence of candidate head of school library in general in the "good" category. Specifically the products of the training program must be maintained and should be increased as much as possible.
\end{abstract}

Keywords: Implementation process of training program.

\section{Introduction}

The school library is the important and integrated factor in educating process in a school in Indonesia. To support the school activities, the library has the functions such as the educative, innovative, administrative, and research functions. The roles of library become very important in the teaching-studying activities in the school. Therefore, a head of school library is a vital person in order to ensure the school activities run well. A head of school library should have the professional ability to handle the library. However, in the fact, the head of library is normally a teacher who is handed over the authority to handle the library. As result the library management is not working well as the expectation. This is due to the fact that the teacher who becomes the head of library is notqualified and incompetent.

In the regulation of Indonesian education mister number 25 in 2008, it is clearly stated that the each head of school library that has the background as the teacher should have the competence certificate in school library management from the authorized institution. Therefore, to raise the competence level of the head candidate of school library head, the educating-training program should be conducted by the candidates.

In Bengkulu City, a city in Bengkulu Province, Indonesia, a concern to the competence of the head of school library is still being the main issue to support the educating activities in all schools in Bengkulu City. Therefore, the educating-training for the candidates is also performed to qualify the right candidates of school library. However, not all education institutions could hold the program in Bengkulu Province, since only the certain institution under the Indonesian Government could do that, such as the authorized institution for education quality, which was known as Lembaga Penjamin Mutu Pendidikan(LPMP) in Bahasa Indonesia. Those institutions are spread out in all capital city of provinces in Bengkulu, including Bengkulu City.

Lembaga Penjamin Mutu Pendidikan, the institution of quality insurance for education, in Bengkulu City together with the Indonesian Library Institution performed the program for the candidates. This 
program should be evaluated to assess the effectiveness of the program to the library management. This study is focused on the evaluation for the increase of education quality, especially for education in Bengkulu Province, Indonesia. The quantitative method which is known as context, input, process, and product evaluations (CIPP) method is employed in this study. The observation is performed to the participants, the human resources, and the organizing committee themselves. In general, this study is addressed to understand the objective descriptions of the program to the candidates in Bengkulu Province.

\section{Theoretical Background \\ Program evaluation concept}

The concept of program evaluation is an evaluation to the set of conceptual, hypothetical, pragmatic, and ethical principle that forms a general framework to guide the study and practice (Stuffebeam and Coryn, 2014). The program evaluation is also used as a tool of the applied research in the managerial process (Padge, 2010). The evaluations are performed as a way to help the people who have to make an administrative decision about human service program. Wirawan (2012) further explained that the evaluation program is the systematic method to collect, to analyse, and to use the information to answer the basic questions about the mechanism of the program. Therefore, the program evaluation can be generalized as a series of activities collect and analyse information to assist in determining effective decisions on a program. Nkwake (2015) mentioned that the purpose of program evaluation is to know the achievement of program objectives by step knowing the implementation of program activities in accordance with expectations. In addition, program evaluation also aims helps practitioners understand the kinds of evaluative decisions they face and enhances their ability to deliberate well. Stake (2011) also explained that the purpose of the evaluation program is to provide the information which is able to guide the decisions concerning the adoption of modification of an educational program.

\section{Training Program Candidates of Head of School Library to Teachers}

Gaol (2013) suggested that the training is more directed to the skill for the current position. Therefore, for all the positions which need the special qualification, th training program should be performed after all. Dessler (2013) explained that the training means giving the new or current employees the skills to perform their jobs. Benowits (2001) stated that the training program is addressed to ensure that the new employee had a basic knowledge required to perform the job satisfactorily. Rao and Nischithaa (2014) revealed that the training program is a learning process to improve the basic knowledge of job description, to sharpen the required skills, to fully understand the rules, attitudes change, and behaviour the performance of the employees. Therefore, the goal of the training program is to ensure the candidates of employee to gets the appropriate knowledge and understanding, so that the jobs could be well performed in the organization.

The training programsfor head of school library candidates are very important to select the competent candidate. The governmentregulation of Republic Indonesia Number 101 released in 2000 said that the education and training for the civil servant position is a requirement before infesting a higher position (PP RI Number 101 2000). The regulation reads that the education and training for the civil servant, hereinafter referred to as training of teaching and learning in order to improve the ability. Basically the training program for the school library principal candidate for teachers is an activity that is designed through the process of providing theoretical experience and practice to the candidate head of the library that has passed the recruitment stage within a predetermined time to achieve the established competencies.

\section{Context, Input, Process, and Product (CIPP) Model}

This model is developed based on the overview that the success of the program is influenced by several factors, such as the human and environment resources characteristics, the aim of the program;the used tools, the procedure and mechanism of the program itself. This model is developed by Stufflebeam (2014) in the Ohio State University.

The CIPP Model is consisted of four important elements. The first one is context evaluation, which is addressed to assess the needs, problems, and opportunities based on the goals and priorities. The context evaluation is also aimed to justify the significance of outcomes. The second one is the input evaluation. This evaluation assesses the approach meeting the needs as a mean of plans to lead the activities. The input evaluation is also aimed to help the explain outcomes. The third one is process evaluation. This evaluation is used to measure the effectiveness of the program. The last one is product evaluation, which identifies the intended and unintended outcomes to help the process on the track 
as well as to determine the effectiveness of the program.

Those four evaluations are oriented to results showing the change occurring on the raw income. Those evaluations results would give an overview of the success of program. How far the effectiveness, the constraints in process, and the solutions?, How is the level of the program implementation? Does the program meet the success?, are the questions which always appear in the evaluation after the program. The CIPP model is a framework to report and evaluate comprehensively. This model has the strong orientation to service and the opened principles to the people. Zhang et al. (2011) revealed that CIPP model is not only used to priassess the impact of servicelearning activity, but also to identify the community needs by working with the community to identify the needs and goals. Those are addressed to formulate a project to meet the identified community project and provide the recommendation for project improvement

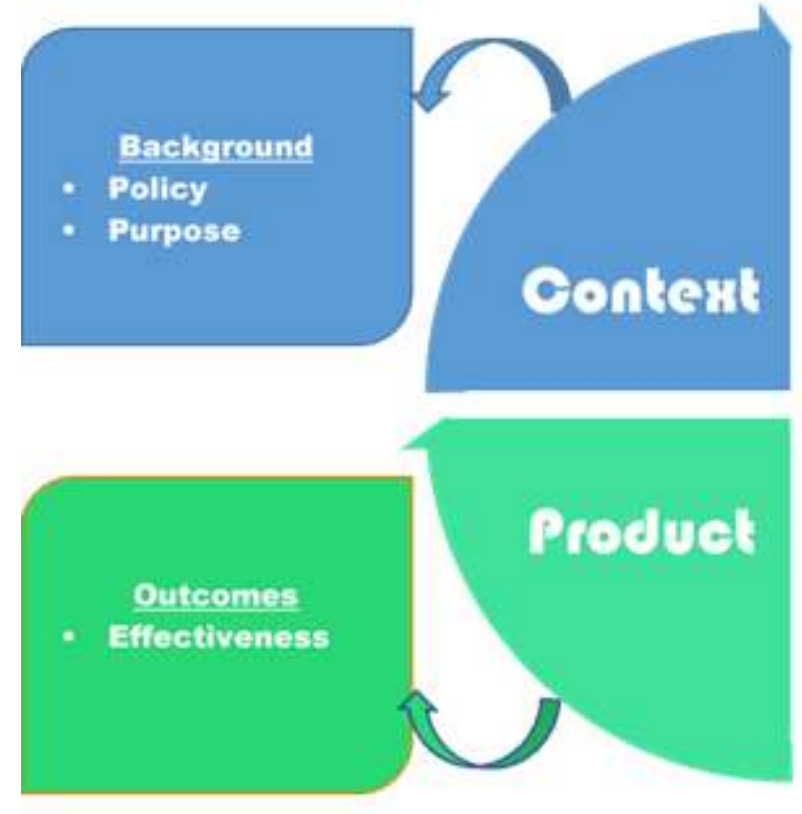

in the future. Therefore, the evaluation could also bring the recommendations to decide which programs are most worthy to continue and which necessary program could be generated from the existing program in the relevant condition (Stufflebeam, 2014).

The model of CIPP is described in Figure 1. It can be seen that the involvement to the goal of the program is in the context evaluation. The contextevaluation measures how far the program is consistent with the reality. The implementation of the program is evaluated by evaluation process. The evaluator monitors, describes, administrates, and notes the sustainability of process through the track record of the program. The product evaluation is more oriented to the results giving the benefit or impact to the positive effect for the program manager as well as the program itself.

\section{Figure 1: The description of Model CIPP (redraw from Stufflebeam, 2014)}

\section{Method of Research}

As elaborated in the previous section, an evaluation to the educating-training program for the candidates of school library head is necessary to perform. Therefore the main objectives of this study are to obtain the description of the program and to measurethe achievement of the program to the competence of the candidates. This study is focused on LPMP Bengkulu located in Zainul Arifin Rd No.2 Bengkulu City; Bengkulu Province, Indonesia with the target of the activity is the candidates of school library head for elementary school, junior high school, senior high school, and vocational high school in Bengkulu
Province. The observation to the study area is performed within six months, i.e. January to June 2017.

This study is initiated by defining the concept of evaluation and how to evaluate. In the current study, the qualitative approach is adopted to obtain the information of the objectives. Several data including the observations, the interviews, the documentations, and the notes are collected. The data is further analysed to obtain the necessary information which is relevant with the objectives. The result of data analysis 
could be the explanation of the research focus, which is presented in the narrative description.

In this study, the CIPP model is selected as the evaluation model. In the model, there are four components that are investigated. They are context, input, process, and product evaluation. All components are evaluated, since they are related to the effectiveness of the educating-training program for the candidates of school library head for school levels in Bengkulu Province. The context evaluation is aimed to identify the readiness of the educating-training program for the candidates. The authors performed a preliminary study to collect the data and information related to the legal basic and objectives of the program. The authors performed the interview to the head of LPMP in Bengkulu Province to obtain the designed program. The results of context evaluation are furthermore used as a background to make a decision to perform the further evaluation, i.e. the input evaluation. The input evaluation is conducted to identify the supporting human resources to succeed the program, such as the facilitator, the committee, target, financial support, facility, training material, structure and program schedule. In this step, the information from the organizing committee, facilitator, and the participants are collected. The authors performed the analyses to the compatibility and appropriateness the human resources to support the program. After the input evaluation is done, the process evaluation is performed. The process evaluation is performed to identify the process of the program. In this step, the recruitment of the program participants, the program implementation, the program monitoring, and the program evaluation are evaluated. The analysis to the criteria and required standard is next performed to dig the information from the organizing committee, the candidates, and the program partner, which in this case is the Indonesian Library Institution, the Regional Library Institution, and the involved School Library. The last evaluation is the product evaluation, which is addressed to assess the standard and required criteria achieved by the participants during joining the program. From this evaluation, the level of fruitfulness from the educating-training program for the candidates of the school library head can be measured, so that the program can be notified as the successful program of not. The results of this study are expected to provide the better explanation of the program and bring the recommendation for the next educating-training program for the candidates of school library head in Bengkulu Province.

\section{Results and Discussion \\ Context Evaluation}

The training program held by the LPMP for the candidates of school library is generally performed under several legal basis such as the Constitution of Republic Indonesia number 20 of 2000 for the national education system, Constitution of Republic Indonesia number 14 of 2015 for teachers and lecturers, Indonesian Government Regulation number 19 of 2005 for National Standard of Education, Regulation of Minister of Education number 25 of 2008 for School Library Standard, Constitution of Republic Indonesia number 12 of 2012 for the authentication of competence certificate, Head of LPMP Certificate number1073/J27.1/KP/2016 on 10 October 2016 for the procedure of training for the candidates of school library head. The results of interview show that the training organizers, i.e. LPMP of Province of Bengkulu, generally have referred the mentioned legal basis in performing the training. In addition, the participants also state that all participants have not had the appropriate knowledge in comprehensive about the legal basis in performing the program before joining the training.

Basically the training has the correct the legal basis, which is more specific explained in Regulation of Minister of Education number 25 of 2008 for School Library Standard. There are several requirements that should be fulfilled, as listed below,

1. The candidates should hold the bachelor degree

2. The candidates should have the certificate of competence for the school library issued from the authorized institution

3. The candidates should have the work experience at least 3 years.

Regarding the legal basis mentioned previously, the interview results reveal that the legal basis of the training for the candidate of school library head obligates the library head from the teaching background who is given the additional position, should have the competence certificate. In general, the aims of the program for the candidates of school library for elementary school, junior high school, senior high school, and vocational school in Province of Bengkulu are

1. To give an appropriate knowledge about the job description of the head of school library 
2. To improve the understanding for the participants in organizing management in school library

3. To prepare the skilled teacher in school library management.

The interview results also reveal that the participant can well understand the goal of the program. In addition, the participants also know that managerial competence, information management competence, educating competence, and personality competence, social competence, and professional competence should been had.

\section{Input Evaluation}

In the input evaluation, the detail related to the training program human resources, the facilitator, the committee, the target of program, the facilities, and the training material, the training structure and the program schedule are presented.

The Facilitator is the one who has the skill in transferring the knowledge to the participant. In LPMP of Province of Bengkulu, there is 14 facilitators who come from the various educational background. Figure 2 shows the educational degree of the facilitators and the facilitators' expertise. In Figure 2a, the result of interview to the program organizers shows that there are 14 facilitators with the qualification of master degree and 1 facilitator with the qualification of bachelor degree. Figure $2 \mathrm{~b}$ reveals that the education background of the facilitators is dominated by Education in English and Management education fields. This shows that the facilitators have the relevant educational background to the training. Generally, the facilitators are qualified as the associate facilitator as shown in Figure 2c. In addition, the interview results also reveal that the facilitators are qualified as the librarian who holds the master trainer certificate from the National Library. The program organizers also invited the informants from the relevant institution to give some lecturers to the participant. During the training, total of 14 informants are invited to give some lectures to the participant. The detail of distribution for the informant qualification fiving lectures in the training is presented in Figure 3.

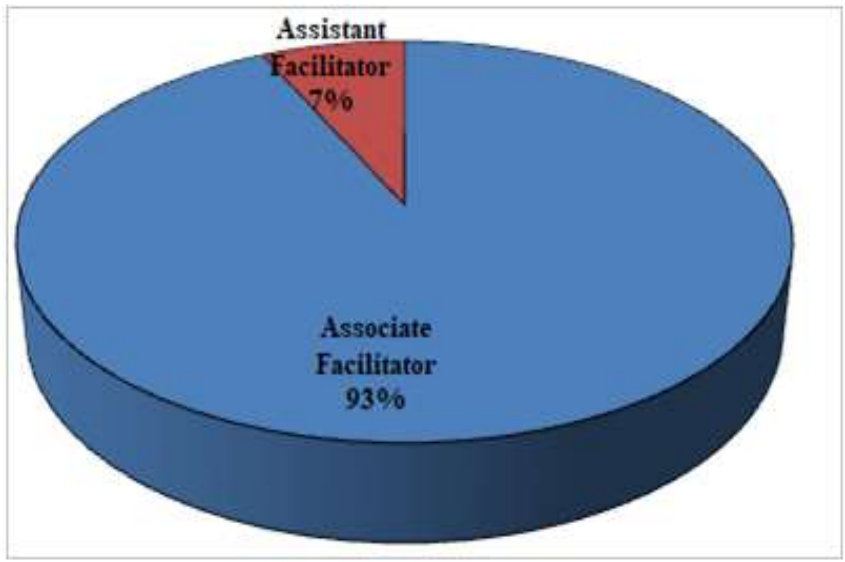

(a)

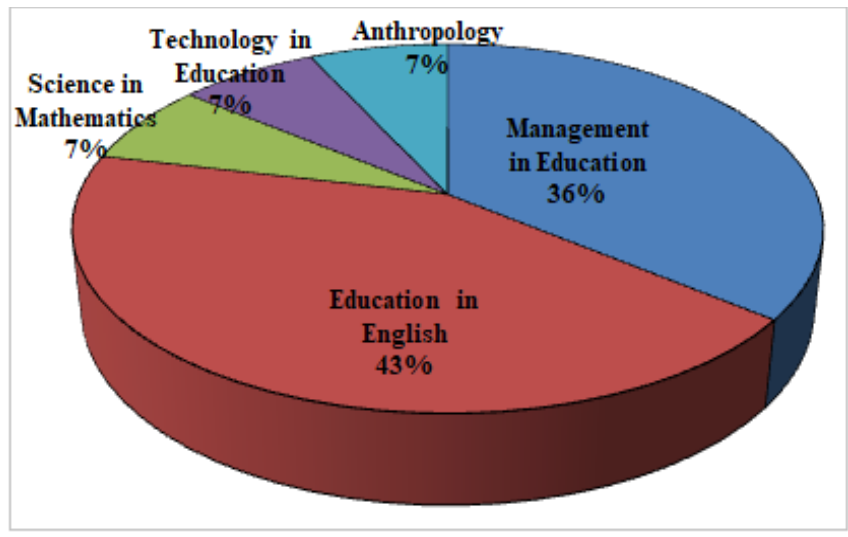

(b)

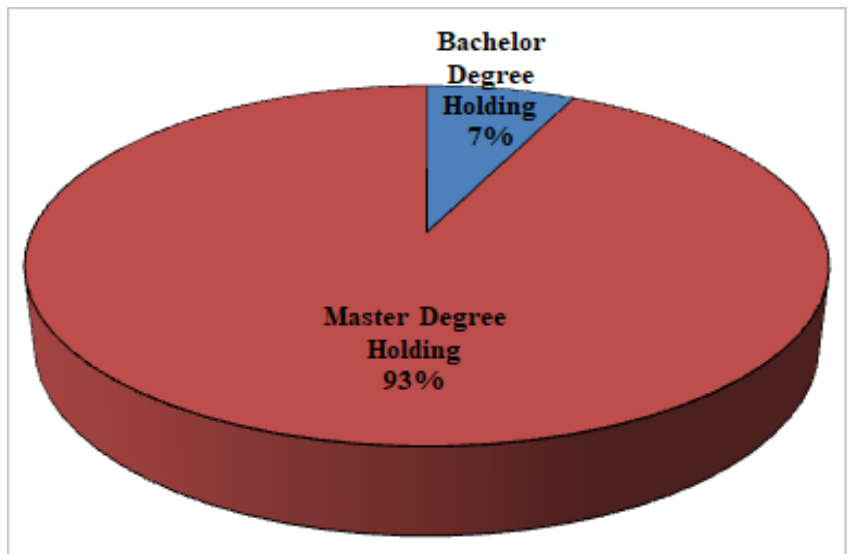

Figure 2: The qualification of the facilitators based on

(a) Educational degree (b) Field and expertise, and (c) Qualification

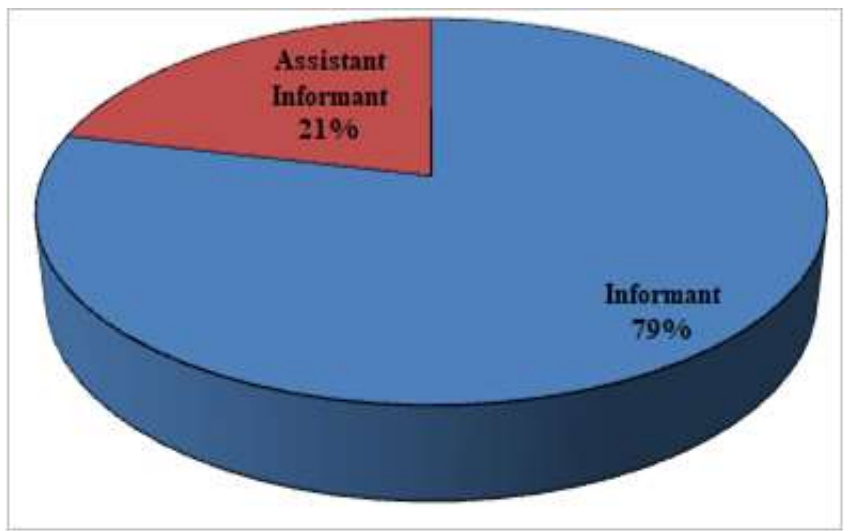

(a) 


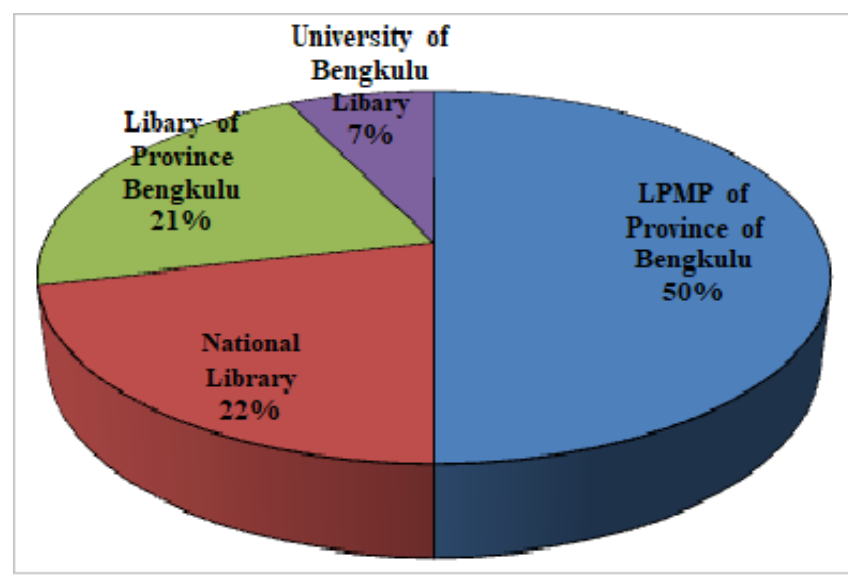

(b)

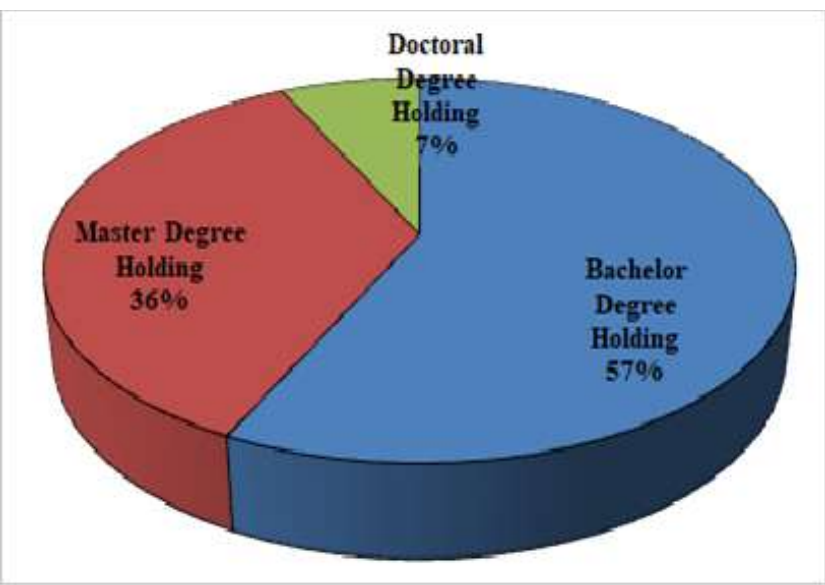

Figure 3: The qualification of informant based on

(a) Level of informant (b) Institution, and (c) Educational background

Figure 3a presents the qualification of the informant giving the material during the training where in majority, they are qualified as informant assisted by the assistant informant .Figure $3 b$ presents the informant qualification based on the institution where they are working on. In general, the informants are working on the relevant institution, such as the university (University of Bengkulu), the training institution (LPMP), the institution of library (National Library and Library of Province of Bengkulu). In addition, the informants are generally holding on the Table 1: List of the number of participant corresponding to the regency city in Bengkulu

\begin{tabular}{|c|l|c|}
\hline No & Regency/City & $\begin{array}{c}\text { Number of } \\
\text { Participants }\end{array}$ \\
\hline 1 & Central Bengkulu & 2 \\
\hline 2 & Kepahiang & 4 \\
\hline 3 & Seluma & 10 \\
\hline 4 & South Bengkulu & 9 \\
\hline 5 & Kaur & 8 \\
\hline 6 & North Bengkulu & 4 \\
\hline 7 & Mukomuko & 9 \\
\hline \multicolumn{2}{|c|}{ Total } & $\mathbf{4 6}$ \\
\hline
\end{tabular}

bachelor degree and master degree, especially the informant from the government institution. Among the informant, there is one informant qualified as doctoral degree that comes from University in Province Bengkulu, i.e. University of Bengkulu (UNIB). From the data presented in Figure 2 and 3, it can be concluded that the facilitators and informants are the structural functionaries. Therefore, the material addressed to the participant is applicable and relevant with what the participants need.

In general, the interview results reveal that the organising of the committee is appropriate. The job description on each member of committee is clear; therefore, the program could be well performed. The committee had already had the experience from the training performed in past, so that there is so many improvement implemented to the program by the committee. The documentation review also explained that there is the decision letter from the head of LMPM related to the structure of committee for the training, i.e. the decision letter of head of LPMP Number No. 1073/J27.1/KP/2016. The decision letter also reveals that the organising consisted of person in charge, person in charge for education division, head of committee, the vice head of committee, chamberlain, the committee member.

The target of the training is to prepare and provide the candidates of school library in Province Bengkulu, the appropriateknowledge. Total of 46 candidates from several regencies and cities in Province of Bengkuluare administratively selected. The total number of participants of the training based on the regency and city where they are working on is presented in Table 1. In Table 1, the participant is generally from Seluma Regency. the number of participant from Seluma, South Bengkulu, Kaur, and Mukomuko are relatively similar in quantity.

For the financial support of the training, the participants have been generally sponsored by the sending institutions. Those participants are placed in the dorm belonging to the LPMP, where several facilities supporting the teaching and studying exist. The participant also obtained the materials of the training that are distributed by the committee. The training was performed for 12 days which was begun at 7.30 and ended at 21.00 .

In general, based on the result of the evaluation, the clearances of the program, the human resource, relevance between the program and the target, the 
financial source of the program, the schedule of the training, the evaluation criteria have been generally fulfilled. In addition, the assessment to the evaluation shows that the input of program has met the criterion, so that this evaluation states that the assessment is consistent with the structural aspect of the program and decent to maintain. However, there is some improvement that could be implemented to the program, i.e. the schedule of the training, which should be revised effectively. This is due to the fact that the training schedule is too congested, so that influence the ability of participant to keep up the training more seriously and effectively. In addition, performing the training for the number of participant more than 30 people in a class is not effective. Therefore, the policy for the quota of the participant in one class should be revised.

\section{Process evaluation}

In general, the process evaluation is addressed to evaluate the activity process. The evaluation is performed to several important stages in performing the training. In this section, the evaluations to the training participant recruitment, learning process, and monitoring-evaluation after the training are presented.

The training participant recruitment is the ideal step before participating in the training. Some administration requirements should be fulfilled firstly. According to the interview, the recruitment has been informed via website as well as the notification letter by LPMP Province Bengkulu. In addition, the detail requirement for the eligibility is also informed. Therefore, there are no significant obstacles faced by the participant candidates in the recruitment. This shows that the information deployment has run well.

The learning process in the training, such as the training material, training method, training medium, and the availability of informant and facilitator is also evaluated. Generally, there is the consistence between the training material and the aim of the training. The use of PowerPoint is aimed for ease the participant to understand the material.

The training method is implemented to the participant in learning process of the training. Based on the interview to the participant, there are several method in the learning process. The first one is presentation, the debriefing, the discussion, the implementation of the theory in simulation and sharing, and the comparative study to the settle library in Bengkulu City. In those training methods, some media in learning practice to support the learning process are used. In the training, the training media used are the white board, laptop, and flip chart. The observation reveals that those media are very effective for knowledge transfer.

To ensure the process of training running well, the competence of the informant should be prioritized. Based on the observation, the informants (detailed in Section 4.3) are very competent. In general, the informants overcome the material. The material delivery is easily understood and the informants are also very keen with the schedule of the training and the neatness in dress. Those are the simple points which can influence the participant to reach all key points in the training. In addition, the informants can interact very well with the participant, so that the participants are not only be able to understand whole material but also to enjoy the leaning atmosphere in the training.

After the learning, the monitoring and evaluation are held. Those are destined to measure how far the participant can apprehend the delivered material. In the training, the evaluation including the pre and post tests are performed. In addition, the assignmentand report prepared by the participant are also used as the point to evaluate the learning process.

In general, the process evaluation to the program would recommend that the evaluated aspects criteria have been fulfilled; therefore, the implementation of the learning process should be maintained and improved.

\section{Product evaluation}

The product evaluation to the program is addressed to measure the results after the training, to assess the success of the program, to identify the unpredictable results, etc. The evaluation is very useful in making the decision related to the sustainability of the program and/or the discharge of program. In this section, the information about the product evaluation including the result of training performance, the knowledge improvement, and the skill improvement is presented. The skill grade is obtained from the practice implementation and the comparative study in the library, whereas the attitude grade is obtained from the discipline, leadership, and team work. Based on the observation, the attitude aspect is seemed from the daily personality of the participant, the knowledge aspect is seemed from the interactive action of the participant to ask and answer the question, and the skill aspect is seemed from the participant in the implementation of the theory obtained in the class to the field. 
The range of the evaluation result to the participant is presented in Table 2. In Table 2, it can be revealed that before the training, the knowledge of the participant could not be appropriate, which is shown by the relatively low score of pre-test. However, after the training, the post test score relatively increase.
According to the observation, there is an increase of $10.37 \%$. In general, the average points of the class is about $76.97 \%$, which can be qualified as "good" as presented in Table 3. Based on the evaluation results, it can be concluded that the participants are eligible to promote as the head of school library.

Table 2: The result of product evaluation

\begin{tabular}{|l|l|c|c|c|}
\hline \multirow{2}{*}{ No. } & \multirow{2}{*}{ Points } & \multicolumn{3}{|c|}{ Categories (\%) } \\
\cline { 3 - 5 } & & The highest & The lowest & The average \\
\hline 1. & Attitude & 100 & 100 & 100 \\
\hline 2. & Pre test & 58.33 & 23.33 & 44.46 \\
\hline 3. & Post test & 66.67 & 41.54 & 54.83 \\
\hline 4. & Achievement & 16.79 & 28.46 & 10.37 \\
\hline 5. & Practice & 81.79 & 78.07 & 79.80 \\
\hline 6. & Formative Aspect & 82.86 & 77.86 & 80.51 \\
\hline 7. & Implementation & 85.00 & 83.00 & 83.87 \\
\hline 8. & The final point & 80.46 & 72.30 & 76.97 \\
\hline
\end{tabular}

Table 3: Level of graduation grade

\begin{tabular}{|c|c|c|}
\hline No & Points & Grade \\
\hline 1. & $95-100$ & Very Satisfactory \\
\hline 2. & $90-94,90$ & Satisfactory \\
\hline 3. & $80-89,90$ & Very Good \\
\hline 4. & $70-79,90$ & Good \\
\hline 5. & $<70$ & Failed \\
\hline
\end{tabular}

\section{Concluding Remarks}

This study presents the evaluation of the training program for the candidates of school library in Province of Bengkulu. The method of CIPP is implemented to evaluate the performance of the training. Several concluding remarks can be drawn as follows,

1. The training program for the candidates of school library has the clear law basis to improve the competence of the teacher in school library management

2. The human resource is eligible to the training program. However, the policy in terms of class capacity and the schedule should be improved

3. The implementation of the learningprocess is consistent with the goal of the program.

4. There is the increase of knowledge in school library management for the participant during attending the training. In majority, the grade level of participant is in "good" category. The evaluation reveals that all participants are eligible to promote as the head school library.

\section{References}

[1] Daniel L. Stufflebeam\& Chris L. S. Coryn, Evaluation Theory, Models, And Applications (San Francisco: Jossey-Bass, 2014), h. 50.

[2] David Royse, Bruce Thyer, \& Deborah Padgett, Program Evaluation (Canada: Wadsworth, Cengage Learning, 2010), hh.1213.

[3] Wirawan, Evaluasi: Teori, Model, Standar, Aplikasi, danProfesi (Jakarta: RajawaliPers, 2012), h. 17.

[4] Apollo M. Nkwake, Credibility, Validity, and Assumptions in Program Evaluation Methodology (Switzerland: Springer International Publishing, 2015), h. 2.

[5] Robert E. Stake, Program Evaluation Particularly Responsive Evaluation. Journal of Multi Discplinary Evaluation, 2011, Vol. 7, No. 15. 
[6] Chr Jimmy L. Gaol. A. to Z Human Capital Manajemen Sumber Daya Manusia. Editor Ninuk Purwanti (Jakarta: PT. GrasindoAnggota IKAPI, 2015) h. 213.

[7] Gary Dessler, Human Resource Management (USA: Pearson Education, Inc, 2013), h. 246.

[8] Ellen A. Benowitz, Principles of Management (New York: Hungry Minds, Inc., 2001) h. 108.

[9] P. Nischithaa and M V A L. Narasimha Rao, The Importance Of Training And Development Programmes In Hotel Industry.International Journal of Business and Administration Research Review, 2014, Vol.1, Issue. 5.

[10] PeraturanPemerintah RI Nomor 101 tahun 2000 Tentangtentang Pendidikandan Pelatihan Jabatan Pegawai Negeri Sipil Pasal 1, Ayat 1.

[11] Guilli Zhang, Nancy Zaller, Robin Griffith, Debbie Metcalf, Jennifer Williams, Christine Shea, and Katherine Misulis, Using the context, input, process, and product evaluation model (CIPP) as a comprehensive framework to guide the planning, implementation, and assesment of service-learning programs. Journal of higher education outreach and engagement, Vol 15 No 42011. 